\title{
For the fear of doctors: a late presentation of lung cancer
}

\author{
Sheila Oh, Jennifer Gilmore
}

Department of Radiation Oncology, Cork University Hospital, Cork, Ireland

Correspondence to Dr Sheila Oh, sheila.my@gmail.com
To cite: Oh S, Gilmore J. BMJ Case Rep Published online: [please include Day Month Year] doi:10.1136/ bcr-2013-200554

\section{DESCRIPTION}

A 60-year-old man presented to the hospital with a large, unusual looking mass protruding from his right infra/supraclavicular region (figure 1). He first noticed a small lump at the base of his neck while shaving and over the course of 6 months, the painless lump grew rapidly and soon extended from the anterior fold of his axilla almost up to his jaw.

He reported feeling dyspnoeic on exertion but denied having haemoptysis. He also reported back pain and bilateral lower limb paraesthesia. He has a 45 pack-year smoking history and had previously worked in the dry cleaning industry. His right arm was oedematous and there was an associated weakness and paraesthesia, consistent with a lower brachial plexopathy.

Despite his worrying symptoms, the patient was reluctant to seek medical attention as he had a fear of doctors and profoundly disliked the idea of being hospitalised. It was only at the insistence of his daughter that he eventually attended his local general practitioner.

A CT of the thorax (figure 2A) demonstrated a large tumour in the apical lobe of the right posterior lung with an associated large infra/supraclavicular nodal mass. The fine needle aspirate revealed an adenocarcinoma. MRI spine (figure 2B) revealed diffuse bone metastases and a soft tissue mass encroaching on the thecal space at S2 level.

The patient declined chemotherapy but was agreeable to palliative radiation therapy (RT). Hypofractionated RT (16 Gray, 2 fractions) was

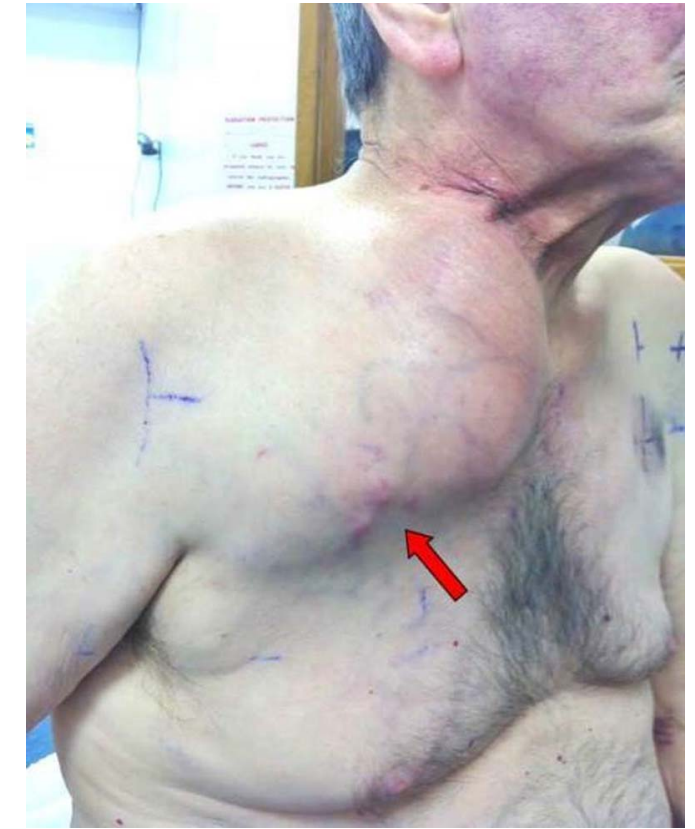

Figure 1 An unusually shaped large mass protruding from the patient's infra/supraclavicular region. There is also an associated area of local skin involvement (red arrow).

delivered to his right upper chest and singlefraction RT (8 Gray) targeted towards the bone lesions.

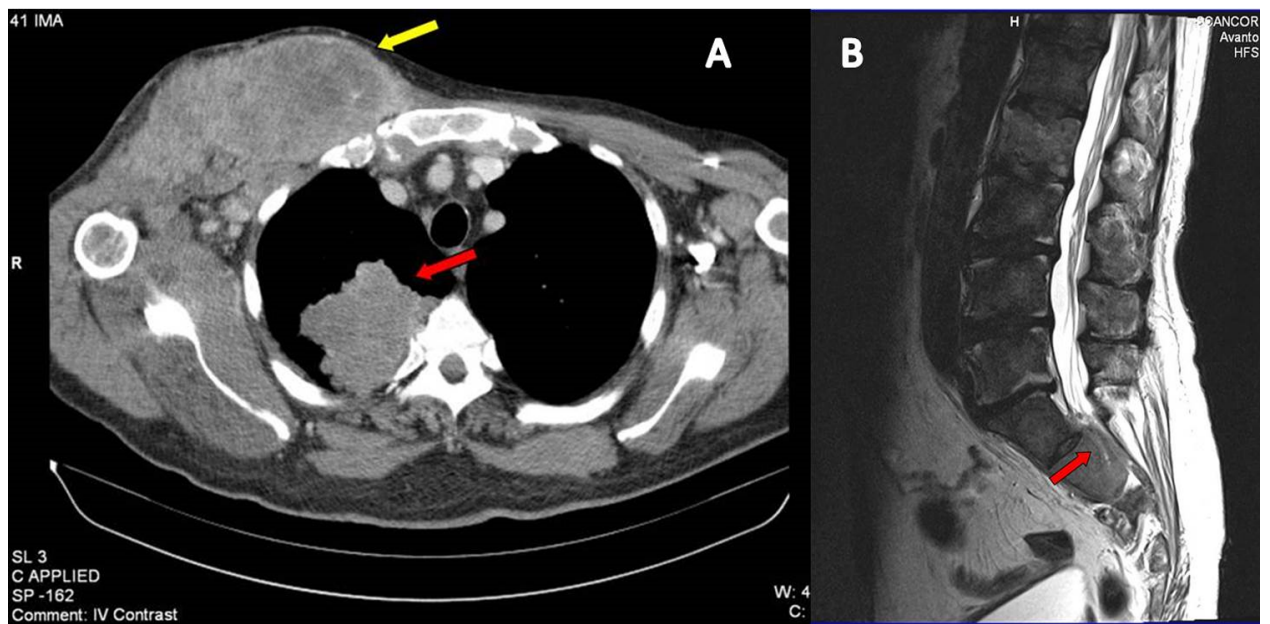

Figure 2 (A) CT of the thorax showing a large tumour in the apical lobe of the right posterior lung (red arrow) measuring $8 \mathrm{~cm} \times 5 \mathrm{~cm}$. The infra/supraclavicular nodal mass (yellow arrow) is also seen here. (B) MRI spine (T2 weighted) showing diffuse bone metastasis. At the level of $S 2$, there is a soft tissue mass encroaching on the thecal space (red arrow). This clinically correlates with the patient's symptoms of back pain and bilateral lower limb paraesthesia. 


\section{Learning points}

- Non-small cell lung cancer (NSCLC) is the most common type of lung cancer. Other than smoking, various chemical exposures (ie, dry cleaning solvent) have been linked to an increased risk of lung cancer. ${ }^{1}$

- External beam radiation therapy (RT) effectively relieves bone metastasis-related pain and neurological symptoms with approximately $80 \%$ of patients achieving palliation. ${ }^{2}$ Single-fraction RT (8 Gray in 1 fraction) has been shown to be as good as multifractionated $\mathrm{RT}^{2}$ ( 20 Gray in 5 fractions or 30 Gray in 10 fractions) in achieving this.

- Palliative RT for locally advanced NSCLC can be delivered as a short course hypofractionated RT (16 or 17 Gray in 2 fractions). Its main advantage is that it enables patients to spend less time in hospital receiving treatment. Studies have suggested comparable outcomes in terms of local control and survival to prolonged standard fractionated RT. ${ }^{3}$
Contributors The manuscript was drafted by SO. JG revised and approved the article for submission.

Competing interests None.

Patient consent Obtained.

Provenance and peer review Not commissioned; externally peer reviewed.

\section{REFERENCES}

1 Brownson R, Alavanja M, Chang J. Occupational risk factors for lung cancer among nonsmoking women: a case-control study in Missouri (United States). CCC 1993;449-54. http://www.ncbi.nlm.nih.gov/pubmed/8218877

2 Kachnic L, Berk L. Palliative single-fraction radiation therapy: how much more evidence is needed? J Nat/ Cancer Inst 2005;786-8. http://www.ncbi.nlm.nih.gov/ pubmed/15928293

3 Lutz $\mathrm{S}$, Chow E, Hartsell W, et al. A review of hypofractionated palliative radiotherapy. Cancer 2007:1462-70. http://dx.doi.org/10.1002/cncr.22555

Copyright 2013 BMJ Publishing Group. All rights reserved. For permission to reuse any of this content visit http://group.bmj.com/group/rights-licensing/permissions.

BMJ Case Report Fellows may re-use this article for personal use and teaching without any further permission.

Become a Fellow of BMJ Case Reports today and you can:

- Submit as many cases as you like

- Enjoy fast sympathetic peer review and rapid publication of accepted articles

- Access all the published articles

- Re-use any of the published material for personal use and teaching without further permission

For information on Institutional Fellowships contact consortiasales@bmjgroup.com

Visit casereports.bmj.com for more articles like this and to become a Fellow 